\title{
MINING, MOVEMENTS AND SUSTAINABLE DEVELOPMENT: CONCEPTS FOR A FRAMEWORK
}

\author{
Anthony Bebbington and Denise Humphreys Bebbington
}

\begin{abstract}
Mining disrupts: it ruptures the boundary between the surface and the sub-surface, it upsets pre-existing modes of living on the surface, it changes biogeochemical, social and economic flows across surfaces, and it transforms imaginations of the future. Mining not only moves mountains, it also moves people - physically, emotionally, politically and economically. Some people leave, some refuse to get out of the way, some carry on, some stay but build new livelihoods, and others arrive in pursuit of the livelihoods made possible by this particular form of development. Development also disrupts: it modifies modes of living and social organisation, it alters relations between humans and nature, it deepens the integration of places into broader flows of finance and ideas, and it shifts ideas about the future. Development is also implicated in the forced, voluntary and induced movement of people. Analytically, mining and development are therefore not dissimilar. This paper works from this similarity to suggest concepts for thinking about the relationships between mining, movement and development. These concepts are drawn from literatures in Human Geography, Rural Territorial
\end{abstract}

This is the author manuscript accepted for publication and has undergone full peer review but has not been through the copyediting, typesetting, pagination and proofreading process, which may lead to differences between this version and the Version of Record. Please cite this article as doi: $10.1002 /$ sd.1888 
Development and Development Studies. It then uses these concepts to frame the relationships between mining and sustainable development.

KEY WORDS: mining; place-making; development; flows; mobility; livelihoods 


\section{INTRODUCTION}

Much of the social science debate on mining has been about whether it is good or bad, desirable or undesirable, guilty or innocent. ${ }^{1}$ This paper steps back from such evaluative arguments, and asks, simply, "How might mining be understood?” Our suggestion is that mining is helpfully thought of as a particular form of development, where likewise we approach development analytically rather than normatively. We suggest one thing shared by mining and development is that they disrupt and re-make place. New flows and movements are central to these processes of disruption and re-making. These movements are of materials, of finance, of people, and of ideas, and the disruptions to which they give rise have implications for what will and will not be sustained over time in, as well as for the identities of, these places. Any discussion of mining and sustainable development can usefully focus on these questions of what is more and less likely to be sustained and how populations in mineaffected regions negotiate these trade-offs. Any normative argument about whether these processes are good or bad only comes after a careful discussion of the processes themselves.

The simple idea underlying this paper is that mining unfolds on land that was embedded in networks of social relations before mining arrived, in places that were being made prior to mining, and in processes of development that precede mining and of which mining becomes a

\footnotetext{
${ }^{1}$ Our own work has certainly not been free of such a thread.
} 
part. These longer histories of place and development are the context in which movement, and the management of movement, in mine-affected areas should be understood. We lay out a series of concepts related to these observations that, we suggest, can help build a simple framework for thinking about the relationships between mining, movement and sustainable development that concern each of the papers in this special issue. The first section of the paper discusses conceptions of place and of development, drawing upon literatures in Human Geography and Development Studies. The second section of the paper adds mining to these discussions, suggesting ways of conceptualising mining in terms of development and place. A third section elaborates on the multiple movements, mobilities and flows to which mining gives rise, and their implications for place-making. The final section then puts these observations in conversation with a notion of sustainable development.

\section{PLACE AND DEVELOPMENT}

Mining projects occur not just at the longitudinal and latitudinal coordinates that define the location of deposits and operations, but more importantly in places that have been produced over time through the layering of human activities. Likewise, mining does not just remove minerals from the sub-soil, it occurs on and beneath land that has prior cultural and productive value determined both by its physical properties, the political economy and forms of capitalism in which it is embedded, and by the social relations that have defined who has access to, and 
can exercise influence and control over, that land. The social nature of land is very much part of the nature of place, and if place can be thought of as location with history and meaning, then land can similarly be thought of as the earth surface imbued with history and meaning. Over time, both land and place have been caught up with processes of development, of which mining expansion is a part. In this section, we briefly develop these concepts of place and development, before relating them to mining in the following section.

\subsection{Place}

"Place" is one of Geography's foundational concepts. As such, trying to pin down single, shared definitions of this concept is unhelpful. For the purpose of our argument we begin from positions laid out by Massey (1991) and Pierce et al. (2011). In a widely-cited article, Massey (1991) argued that places are, and have long been, embedded in global flows of people, money, ideas, products and more. She developed this position in opposition to politically conservative notions of places as having "essential" identities that should be protected on the grounds that their "essence" was being threatened by the arrival of persons or things from "outside". In contrast to these renderings, a "global sense of place" makes clear the sense in which places are in processes of constant production and reproduction, and do not exist separately from such processes. At the same time this "global sense of place" would make more visible the ways in which some places have benefitted historically from relations of 
dispossession and the transfer of wealth from elsewhere, and that their present nature is partly a product of such inequities. A global sense of place would be progressive, cosmopolitan and historically aware.

Pierce et al. (2011) develop this idea, arguing that rather than speak of "place" it is more appropriate to speak of place-making, understood as "the set of social, political and material processes by which people iteratively create and recreate the experienced geographies in which they live" (ibid: 54). Like Massey, they insist on the "inherently networked" and political nature of this place making - in ways that are redolent of Escobar's arguments about culture and place (developed from his own work in Colombia: Escobar, 2001; Escobar, 2008). How place is negotiated is also closely related to the livelihoods pursued in those places, and so when livelihoods are in transition, places are likely in processes of transformation (Bebbington, 2000). Places are always being negotiated among actors through relationships that are asymmetric and which link different locales and scales. This inherently negotiated process, mediated by inequalities of power, renders place-making always a political phenomenon. Furthermore, Pierce et al. (2011) insist that "place-making" is not just local, but rather a scaled process that involves actors in different locations, and occurs at regional, national and global scales (debates over global environmental change being, in some sense, negotiations over what sort of place the earth is). Indeed, a "place" may be understood in multi-scalar ways in the sense that a given locale may be understood also in terms of the identities of the regions and 
nations of which it is a part (arguments over the meaning and identity of Catalunya/Catalonia would be a case in point).

"Place" is closely related to the idea of "territory," a concept that features more prominently in Development Studies and Politics (Schejtman and Berdegué, 2004; Escobar, 2008; Berdegué et al., 2015). Territory also implies a "locale with identity" that exists in relation to how power and authority are exercised over the locale (as in "whose territory is this?"). Territory by definition implies a networked politics of negotiation in so far as territorial claims are always relative to other claims over the same locale, and territories always exist in negotiated relationships to each other, horizontally (as in contestations over boundaries) and vertically (as in contestations over authority).

In summary, place and territory are constantly being made and remade, negotiated and renegotiated, in relationships that reach across different scales and in relationship to processes and flows that link locales through movements of money, things, ideas and people.

\subsection{Development}

In contrast to discussions of how far "development" should emphasise economic, human or environmental aspirations, or of whether development has or has not occurred, Cowen and 
Shenton $(1996 ; 1998)$ sidestepped all such evaluative considerations with a conceptualisation that two decades later continues to be used widely in critical studies of development. They distinguish between two meanings of the term. First is development understood as an immanent process, in which the inner nature of an organism or a system works itself over time. In discussions of socio-economic change, this is manifested primarily in a notion of capitalist development (as the unfolding of the inner logic of capitalism) but also in notions of societies developing over time towards some sort of end-point. Second is the notion of development understood as an intervention, in which an actor intervenes to contribute to the "development" of another: as, for instance, in efforts to promote child development, rural development, or industrial development. This form of development is, they argue, necessarily predicated on a relationship of trusteeship, in which the purposes of the intervention are conceived of by an actor acting on behalf of the betterment of the object of the intervention. In the first sense of development, the endpoint is defined by the inner logic of the system; in the second sense, it is defined by a social actor presuming to know better. The two can be related, as in project interventions that seek to speed the internal development of capitalism, though it remains the case that interventions seek this goal because those assuming the role of trustees decide that the endpoint of capitalism is the betterment toward which a society should be directed. This relationship between teleology and intervention is also present in arguments about democracy, viewing it as an ultimate end point whose arrival intervenors seek to hasten because they believe that democracy is universally good for others (cf. Sen, 1999). 
In each of these conceptualisations, development intersects with place. In the first sense of "development", capitalist development operates through place based processes, and places are both products of, and sites that produce, capitalism. Historically, land and natural resources have been at the centre of such capitalist development - whether through acts of dispossession and primitive accumulation, or the incorporation of land based agricultural products into new markets. As the last decade of literature on land grabs shows, such processes continue (Borras et al., 2011; Edelman et al., 2013). In such dispossessions and incorporations, land is taken out of some social relations and becomes embedded in others, and the meanings of land and places are challenged and changed. As these processes unfold, places become linked to other places in ways that are combined, uneven and increasingly global (cf. Massey, 1991; Massey, 1984). At the same time, as sites that are lived in and made meaningful while also embedded in socio-economic logics that exist beyond particular locations, these places acquire (contested) identities that are produced as much by everyday life as by broader processes. In the second sense of "development", almost all interventions are targeted at places, from the very local to the national. These interventions introduce new flows of resources and ideas into those places, and introduce new actors into the negotiations over what constitutes the identity of those places. 
As development intersects with place, it also intersects with the diverse negotiations and livelihoods that constitute part of place-making. In the process, development, both as capitalist development and as interventions, shifts the hierarchies among and opportunities open to those livelihoods and to the people who produce and negotiate place. Some people gain from development, others lose, some people's ideas of what a place should be are elevated, others are not. Insofar as place-making is affected by the nature of these shifting differences among people, and the ways in which they are given meaning and negotiated, so the flows associated with development change the nature of places: they remake places through the new differences that are produced because of development.

\section{MINING, PLACE AND DEVELOPMENT}

\subsection{Mining places}

While rarely framed as such, debates over mining can usefully be thought of as debates over place and place-making. In arguments over whether Peru should be thought of as a "mining country" or a "megadiverse country", proponents are arguing over the identity that should be ascribed to a geographical area - over the "meaning" that Peru has to them, and the meaning that should be conveyed to others about Peru. When indigenous populations in the Amazon or Chaco regions of South America insist that an area is their territory, and not a natural gas or 
oil field, they are also arguing over place-framings and identities. When traditional authorities in Ghana emphasise their historical powers to govern areas that are now affected by mining or hydrocarbons, they are not only defending their interests, but also making a point about the relationships between territory and power, and which forms of authority should matter in processes of place-making. Efforts to reconcile such discussions by arguing that such spaces can be both, i.e. indigenous territory and gas field/mine site, are no less attempts to frame a place identity, as, for instance, when indigenous people in Papua New Guinea claim certain regions or lands as their territory precisely because they also want to claim ownership over the minerals within this land and the benefits to be derived from the extraction of these minerals (Filer, 1997). When residents of Tambogrande, Peru argued against the proposed Manhattan Metals mining project, the argument that economic activities in the valley should prioritise the production of limes for ceviche, rather than of gold for export, was an argument over the identity of a place (captured so vividly in Cabellos and Boyd, 2007). That the departure of Manhattan was followed by the arrival of small-scale miners does not change the point. This arrival has produced new negotiations over a different sense of place again.

The locations where mining projects occur were already produced as places prior to these projects. Mining and some sort of relationship to national and global flows of minerals may already be part of those place identities, as when a new mining project arrives in the Copperbelt of Zambia, or the Ashanti region of Ghana. In other instances, mining and the 
global relationships that it brings will not have been parts of those identities. As Pierce et al. (2011) might remind us, nor were those prior identities ever fully settled: they were always being negotiated and produced, politically and socially. The actual or potential arrival of mining further unsettles such negotiations over place making, and introduces an additional set of factors that will contribute to the making of place: new capital flows, new landscape modifications, new work and workers, new conflicts, new meanings ascribed to all of these phenomena. Mining affects place-making profoundly. This is the case regardless of whether a project ultimately proceeds or not, for even if it does not proceed, all the negotiations, ideas about the future, aspirations and conflicts that were present during discussions of the possible project cannot be forgotten, and become part of the sense of place in that location. Likewise, when mines close, memories of mining continue to constitute how place is interpreted and made meaningful.

The mining sector itself becomes a conscious agent in this place-framing. Efforts to promote the idea of a sustainable mining enclave, or of new local economies based on opportunities opened by mining's arrival, are also efforts to affect place-framing processes. This can be as much the case for large-scale mining as for artisanal and small-scale mining (ASM). Indeed, just as it can be associated with narratives of illegality, ASM is also associated with narratives of livelihood and possibility that seek to reframe ideas about what ASM places might become as frontiers of new opportunities (Maconachie, 2014; Hilson et al., 2017). In yet other cases, ASM 
may be framed in terms of its long-standing, place-based synergies with smallholder agriculture, as Spiegel (2014) suggests for Cambodia, and Maconachie and Binns (2007) for Sierra Leone. These are all attempts to cast imaginations of mining areas, such that those imaginations of the future will make possible particular forms of mining investment in the present. Counter-narratives that suggest that such locales could be niche producers of agricultural products, or carbon sinks as intact rainforests, and so do not need mining, do exactly the same. Thus, mining changes not just the contemporary experience of place but also the ways in which imaginations of the future of a place affect that contemporary experience and sense of place.

The sorts of place transformation triggered by the new flows of ideas, people and money that accompany the arrival of mining are particularly well captured in the work of Ximena Warnaars in S.E. Ecuador (Warnaars, 2013). In her ethnography of the town of El Pangui, Warnaars documents how arguments over the desirability or not of a large-scale mining project transformed residents' everyday experiences of the town. Disagreements over mining played out in decisions to frequent some beauty salons and boycott others, in name calling in the street, and in fights among children in the school playground. Negotiations over what sort of place El Pangui should be in the future, were transforming the everyday experience of El Pangui as a place in the present: all this before the mine had even arrived. 


\subsection{Mining as development}

In the same sense that mining is place-making, so also mining is development - in each of the senses distinguished by Cowen and Shenton (1996). Mining is part of an immanent process of capitalist development. Mineral extraction was at the core of the creation of the modern world system, especially in the form of the gold transferred from Latin America into Iberian and European economies (Wallerstein, 1974), and mining has frequently been at the forefront of early stages of colonially led primitive accumulation, with colonial mining companies being important players in early periods of capitalist development in different colonies. Mining has been part of the extension of capitalism across the globe, linking together places in processes of combined and uneven development. Likewise, mining has been and continues to be a form of development understood as intentional intervention. The intentions at play here are not only those to develop a deposit, but also the collateral intentions that often accompany a mining investment. As just one example of such a collateral intention, we might note the goal of viewing a mining project as a vehicle for extending the state's capacity to govern into new locations, both directly as well as indirectly through the state infrastructure that can be financed by the revenues generated from mining. In the following paragraphs, we expand on what mining does as development in these two senses.

\subsection{Mining as capitalist development}


Mining extends capitalist development to frontiers in which the capitalist economy is not institutionalised - it can do this either in the form of large-scale capitalist investment (as in large mines in the Papua New Guinean highlands) or of informal and illegal mining (as in the arrival of such mining in indigenous territories in Madre de Dios in lowland Peru, or in conservation areas in Indonesia). Mining can also introduce new forms of capitalism into areas that are already incorporated into the capitalist economy, but through distinct forms of capitalist production. The arrival of the Yanacocha mine in Cajamarca, Peru, for instance, introduced into an area already characterised by petty commodity production and agrarian capitalism (Deere, 1990), a new capitalist form characterised by accumulation on a large scale combined with significant dispossession and disruption through large-scale land acquisition. In these different instances, mining has the effect of shifting incentive structures and so inducing new forms of human behaviour (as well as forcing other forms of behaviour). It also tends to change the relationships between political structures and economic functioning. If one accepts the argument that markets and policies are embedded in particular sets of social and political relationships which influence the types of market that form, how they operate and how they are regulated by policy, then to the extent that mining induces the emergence of new elites, the further consolidation of others, and the weakening of yet others, its arrival in a locale (whatever the scale) will influence the forms taken by capitalism in those locales. 
Furthermore, mining affects the geography of capitalist development in ways related to the nature and geography of deposits, as well as the geography of prior political arrangements (Bridge, 2004; Bebbington, 2015). Again, the contrast between Madre de Dios and Cajamarca in Peru is illustrative here in so far as each have seen the deepening of particular forms of capitalism over the last two decades, but in ways that are related to the nature of deposits in each region. Madre de Dios's alluvial deposits elicited a regional form of frontier capitalism based on ASM forms of production, accumulation and exchange, while Cajamarca's dispersed, rock-based, sub-soil deposits elicited a regional capitalism structured by the concentration of capital in transnational companies establishing a presence in the region. The more general point is that more than many economic activities, mining has a constrained geography, and so it gives rise to particular geographies of capitalist development.

\subsection{Mining as intentional development}

Mining is also implicated in a series of quite intentional interventions that seek particular ends. These interventions are directed, above all, at managing populations, policies and the physical landscape in ways that facilitate the extension of mining investment as well as of other sociopolitical projects. In order to secure land for operations, mining pursues land acquisition, resettlement and compensation programs. These seek to move populations away from areas to be mined, and establish them in activities and settlements located elsewhere (this is also a very 
particular form of place-making: Owen and Kemp, 2017). These interventions have every incentive to succeed in order to secure on-going consent for the mine and avoid disquiet and protest from relocated populations. Other interventions may include the conscious building of settlements in order to attract in the sorts of skilled labour that a mine needs in order to operate.

At the same time mining pursues a series of other interventions that also seek to secure the consent or at least tolerance of populations, understood as a social licence to operate (Owen, 2016). Some interventions are supported through company Corporate Social and Environmental Responsibility programs, or programs of social, community and small business development - interventions that look very similar to the longer history of rural and community development programs on which they draw for lessons, and that can often fail precisely because of constraints and incentives established by immanent development (Banks et al., 2017). Other interventions can also include massive programs of urban renewal, or water supply and desalination, that bear more resemblance to projects on the size of modest World Bank loans than to community-based projects. What these large interventions share, however, is the goal of regulating populations such that they give assent to mining investment. This is not to say that the programs may not also be motivated by a genuine sense of responsibility, nor all actors within companies have exactly the same motivations in their work - but the primary effect sought at a corporate level is to secure assent. 
In these different interventions, the mining company engages in a form of trusteeship in the sense conveyed by Cowen and Shenton (1996). They assume a responsibility for a local population and they define elements of a desirable future for that population. They then try to steer that population towards that future. How, and how well, they do this varies greatly depending on the nature of the company and its prior experience. Major companies and junior companies, for instance, can operate very differently in this role of trusteeship, reflecting their different capacities, their different time horizons, and the intentions that underlie their interventions. Junior companies tend to have shorter time horizons, are constrained by the more immediate motivations of the speculative capital on which they depend, and are primarily motivated by the goal of designing and securing a project that they can then sell on to larger companies. Their notion of trusteeship is often much more time constrained than that of the larger companies who end up operating the mines, and need to secure assent over a period of several decades.

While the foregoing illustrations conceive of "mining as intentional development" at the level of individual projects and companies, it is also the case that governments seek development goals through mining. In some instances, they may do this as a company (the state mining company), while in other cases they intervene through policy aiming to facilitate mining expansion in certain parts of the national territory. In other instances, government may also 
intervene to constrain mining development, both large-scale (as in those countries that have sought to prioritise environmental concerns over mining based capitalist accumulation: Bebbington, 2012; Broad and Fischer-Mackey, 2017) and small-scale, as in those instances where government criminalises and seeks to restrain artisanal gold mining on the grounds that it is illegal, destroys the environment, does not pay taxes, or is associated with collateral forms of "anti-social" and illicit practice. In each of these roles, whether promoting or constraining mining, government takes on the role of trustee, mobilising mining in pursuit of a particular view of the future that political authorities deem should be lived by citizens. While government motivations may also ultimately be to secure the viability of mining investment, the larger aspirations at stake differ from those of individual companies. These broader objectives might include securing on-going political support from labour (for instance, the Government of Zambia in the 1970s seeking ongoing support from workers in the Copperbelt), securing national boundaries through installing mining projects close to international borders, establishing new forms of political order in areas deemed by government to be otherwise prone to illegality or oppositional politics, or more generally deepening the idea that their country is, or could be, a "mining country" (as, for example, in the government of Ecuador's determination to promote large-scale mining over the last decade). Such goals may not align perfectly with corporate goals. For instance, the geographies of mining aspired to by a government that seeks to extend political order may not be the same geographies that would be generated by investments responding only to the constraints of capitalist viability. Under 
such circumstances, governments may use tax holidays, public subsidies or state sponsored supporting infrastructure to reduce the differences between these different geographies.

The allocation of authorities between central and subnational government also has implications for the ways in which government uses mining as a vehicle of intentional development. A particularly extreme case of this has been in Indonesia where the devolution of authority to grant mining licenses from central government to district government led to an increase in the number of mining permits from 750 in 2001 to more than 10,000 in 2010. Various factors drove this explosion in subnational mine licensing. In some cases, licenses were issued as an honest element of a local economic development strategy. In other cases, the motivation was to stimulate investments that would contribute to district government revenue. In yet other cases, licenses were issued in return for payments, either direct to the subnational governments or to authorities' own re-election campaigns (Jong, 2018). In some cases (e.g. South Kalimantan), authorities have issued licenses to illegal local miners operating within concessions of larger mining companies, because these local miners contribute more revenue to the region than do the central state-licensed mining companies. Whatever the motivation, licenses were issued rapidly, and often unsystematically, overlapping with other natural resource concessions (e.g. for oil palm, logging, pulp/paper, etc.), protected areas and other mining licenses, producing places with increased tension and environmental damage and complicating processes of capitalist expansion. 


\section{MINING, MOBILITY, FLOWS AND MOVEMENTS (PEOPLE, THINGS, MOBILISATIONS)}

Understanding mining as simultaneously immanent development and intentional development helps make the point that mining-related activity seeks to have certain effects, while also having other effects in addition to, and to some degree regardless of, the original intended effects. In seeking a way to talk about these different types of effect, the language of movement, mobility and flows can be helpful. Many of the undesired effects of mining hinge around movement, while many of the effects that mining seeks to have revolve around the management of movement (see Bainton and Banks, 2018). However, not everything nor everyone necessarily moves in the ways that mining seeks. The combination of these different sorts of flows and movements leads to the new forms of production of place that are triggered by the arrival of mining in a locale. In this section, we elaborate on some of these ideas.

Mining "takes place" and is made possible in place, and then changes that "place", through a combination of "movements in", "movements out" and "erasures." In each of these ways mining is part of processes of place-making. As a mining project moves forward it is made possible by movements into a place of investment capital, materials, energy, water, technology, knowledge, ideas, workers and money (paid to workers and suppliers). These different flows 
have to be made to converge on the mine site, and adjacent areas, in order for the mine to be possible. At the same time, the possibility and profitability of the mine also require a series of "movements out," either from the immediate mine site, or from the wider region within which the mine site is located. These movements out are of "waste" materials (the removed overburden, the separated tailings), ore concentrates and the mineral itself. There are also movements out of people when they have to be resettled because of mining, and of financial capital, in the form of the value inhering in the minerals that has to be sent elsewhere to reward the investment capital that made the mine possible.

If these are the required movements, another set of movements in and out occur as effects of mining though they are neither intended by, nor entirely within the control of, the mining company. These movements are also material, financial and human. The most significant material movements that can occur are those related to water contamination, when the arrival of mining leads to the unintended and undesired movement into water of chemicals that have been rendered more mobile because of mining activity. Other material movements, such as slope or tailings slippages are much more episodic and rare, but nonetheless constitute a risk that must be managed. Financial movements-in can include the incursion of speculative capital seeking to profit from the presence of mining. Such inflows of capital can lead to unplanned settlement growth, inflated rental and property markets, and investment in new service enterprises that can run the range from vehicle workshops to brothels. Other movements-in 
can include transfers of tax payments and royalties back to regions where extraction occurs, though if and on what scale such transfers occur depends on national legislation and political debates. These fiscal movements-in also transform the nature of a place as they incentivise new forms of behaviour, induce new investments, and often catalyse new social and political contestations within regions as well as between them and other levels of government (Arellano-Yanguas, 2012). Financial movements out can include the transfer of enterprise profits or compensation payments out of the region, such that they do not benefit the local economy. The most significant human movements-in are of labour (dominantly male) seeking employment opportunities in an economy imagined as growing and vibrant because of new mining. Other movements include the return of former residents hoping to re-establish residence and secure compensation payments. Human movements-out can include people who receive compensation payments and use the money to leave, or others who for different reasons see no future in the face of mining and simply leave.

In some sense these different unplanned movements reflect responses to the economic and geographical disequilibria introduced by mining investment. Labour markets, water tables, slope gradients and ionic exchanges all seek new equilibria, while finance moves to (perceived) better investment opportunities. Yet these new equilibria do not necessarily favour the viability, social licence or environmental sustainability of the mining project. As such, just as the mining enterprise seeks to manage the movements that are necessary for the initiation of 
the project, so another goal of its intentional interventions is to manage these financial, human, hydrological and geomorphological responses to the disequilibria introduced by the investment. The list of interventions here is long, and wide ranging. It includes: experiments with fly-in/fly-out management of labour; the introduction of increasing automation, again to reduce influxes of labour; training in healthy sexual behaviour among mine workers; distributed water quality monitoring systems; tailings management systems with multiple inbuilt redundancies; economic diversification initiatives to keep new investment capital in the region; among others. Seen at a given level of abstraction, all of these apparently disparate interventions are similar in purpose in that they seek to manage and to cope with movements that have been elicited by the presence of mining. Or, in the language of the previous section, a large part of intentional development on the part of mining companies and some government agencies can be understood as efforts to manage the new flows and mobilities that are unintentionally, though inevitably, catalysed by mining investment.

Of course, not all movements or flows are equally powerful, and so while movements in and out are in part responses to new disequilibria, they also reflect asymmetries of power. In these asymmetries, power is exercised through the mobilisation of wealth (allowing companies to bring in workers, machinery etc.), of force (through which state or private security forces create conditions to facilitate the arrival of new investments), of legal instruments (facilitating movements in of money and the relocation of populations), of litigation (used both to enable 
and to block new investment depending on the actor using litigation), of bodies (used by populations to mobilise physically and collectively against the arrival of mining), and of ideas (in which actors use media and other instruments to promote certain ideas and narratives about mining). Government agencies, corporations, artisanal and small-scale miners, communities, and civil society organisations are differently placed in these asymmetries, and while in an aggregate sense companies and governments appear as the more powerful actors, better able to enforce and restrain the movements of their choice, this is far from always the case and the webs of power at play in these asymmetries are often complex and shifting, as actors change positions, gaining and losing leverage at different times.

These different movements-in and movements-out, coupled with efforts to manage, resist and negotiate them, have the further effect of reframing place and changing the politics of placemaking. If - to follow Pierce et al. (2011) - place is a product of flows and networks that pass through a locale while connecting it to other places and scales, then the dramatic change in movements and flows due to mining development (as both capitalist and intentional development) necssarily re-makes place. These flows unfix some aspects of place, fix other aspects, and in general trigger new negotiations over the meaning of place. The harshest sense in which this occurs is through the simple erasure of prior cultural and material landscapes. Iconic cases of such erasures might be the removal of symbolically important mountains and rivers, or the wholesale resettlement of communities and their graveyards (e.g. the San Andres 
mine in Honduras). In other cases, the act or threat of such erasure may also lead communities to revalorise landscapes and give them new or rediscovered symbolic significance (as in the case of the Ailaya complex at the Lihir mine in Papua New Guinea, see Bainton et al., 2012). The re-making of place can also occur through processes that are less drastic than erasure: new people in the main square on weekends, new building styles in the local town, increased vehicular traffic, changing noise levels in everyday life, new conflicts with neighbours because of differing opinions over the desirability of mining and its consequences, new living arrangements as rental prices increase and longstanding residents have to move house, priceinflation in food markets, the building of new private schools for mine staff, and so on.

In addition, to the extent that there is a close relationship between place formation and livelihoods (Bebbington, 2000; King, 2011), then the spatial reorganisation of livelihoods resulting from mining also has implications for the production of place. In a different context, King (2011) has demonstrated how the setting aside of land for protected areas in South Africa changes the geography of livelihoods as families lose access to some assets and seek access to other assets located elsewhere in order to build their livelihoods. Bury (2004) showed something similar for communities differentially affected by the Yanacocha mine in northern Peru. As patterns of movement associated with livelihoods change, so does sense of place. In the extreme case, a sense of place can come completely undone as whole populations lose access to land and move out in order to build livelihoods elsewhere. In such cases, while 
livelihoods may be refashioned and sustained in new ways, place is not sustained: it continues as memory but not as everyday experience.

In some instances, however, people refuse to shift their livelihood geographies and give up on prior place attachments. Such refusals "to move out" trouble mining projects, and also affect senses of place. A recent, and globally significant, case of such refusal also comes from the areas affected by the Yanacocha project. This is the case of Maxima Acuña's refusal to move from her farm site in an area affected by the project, Minas Conga. This refusal elicited further efforts from the mining company to attempt to manage (and ultimately force) Sra. Acuña's movement out - and these attempts were in turn met by a continued refusal to move. The case became a national and international cause, leading to legal proceedings and special inquiries, as well as academic presentations and NGO campaigns and the recognition of Sra. Acuña with a Goldman prize in 2016. In this instance, the combination of capitalist development and company intervention was unable to elicit a movement out, leading to a stalemate that has blocked the project and ultimately contributed to it being put on hold. It has also produced a very different sense of place in the area of Maxima Acuña's small farmhouse.

The Acuña case illustrates a final sense in which mining can elicit movements that it then seeks to control. These are the social movements that emerge in response to extractive industry investment and that, like mining projects, are also made possible by the convergence on a place 
of financial, organisational, ideational and human resources. These social movements are triggered by the flows and movements elicited by mining, and come into being to contest these flows. While the motivations for such contestation are varied, in some instances they are related to the ways in which place is being reframed and reproduced by mining. These contestations in turn challenge these reframings of place and constitute another element in the negotiations that occur over the meanings ascribed to locations affected by mining. In turn, such movements elicit interventions from mining companies to manage them, both in anticipation of, and subsequent to, their emergence: attempts that can run the range from negotiation to litigation, intimidation and murder (Global Witness, 2017).

\section{MINING, MOVEMENT AND SUSTAINABLE DEVELOPMENT}

Peter Benson and Stuart Kirsch (Benson and Kirsch, 2010; Kirsch, 2014) have argued that the idea of "sustainable mining" should be understood as a "corporate oxymoron", part of a "set of strategies used by corporations to manage or neutralize critique" by linking the activity of mineral extraction to what they call a "desirable cover term" (Benson and Kirsch, 2010: 45). While some might likewise view "sustainable development" to be an oxymoronic "desirable cover term", "sustainable mining" and "sustainable development in mining regions" are somewhat different concepts. While the former suggests that the very activity of mining can be sustainable, the latter implies a weaker claim, namely that after a full accounting for all the 
effects of mining in a region, the net financial, human, social and natural capital stock of that region could increase in a way that broadens options for future generations (Serageldin and Steer, 1994; WCED, 1987). Therefore, while we would agree that "sustainable mining" is indeed an oxymoron used deliberately to cloud debate, and that "sustainable development" can be used in a similarly obfuscating way, we also suggest that it is quite possible that mining can be part of a process of change that would be understood as sustainable development in the terms laid out by Serageldin and Steer (1994), or by the Brundtland Commission. Whether it is or not is an empirical question, not a definitional one.

Drawing on ideas discussed in the previous sections, there are several implications for how one might think about the relationship between mining and sustainable development. First, this relationship is part of a process of capitalist development and therefore characterised by the same dynamics and tensions as occur in capitalist expansion in general. Second, within this process, different actors will intervene in the lives of others, each with their own forms of trusteeship and guiding ideas about what sustainable development should look like. Third, the process will be characterised by a range of disruptions, flows and movements that remake places. Fourth, beyond any net change in capital stocks in a region, whether these forms of development might be deemed sustainable or not will depend on how far the populations involved are able to negotiate these different place-framings and disruptions in such a way that 
residents are able to continue living together peacefully and perceive improvements in their lives and livelihoods.

In summary, mining is an immensely disruptive activity that, whether large-scale or small-scale, introduces new flows into and out of the locations in which it occurs, and in so doing transforms the nature of places. It also introduces new "trustees" of development into these places. These trustees have a strong sense of what development should look like, and thus of what these places should look like, and they do their utmost to manage the movements and flows that are triggered by mining so that these visions of development and place can be secured. However, not all these movements and flows allow themselves to be managed: some contaminants still flow beyond the mine sites, some residents refuse to be resettled, some inmigrant workers behave badly. These ungovernable movements give rise to disquiet and at times protest, and create the space in which alternative ideas of place are framed. Ultimately, the possibility that a mining region might experience something that would pass as sustainable development in the terms laid out by Serageldin and Steer (1994) will depend less on how well the mining company can contain the governable movements to which its presence gives right, and much more on how far the movements that escape its control create conditions for more inclusive and meaningful debate on the idea of place and development around which a wide range of stakeholders can converge. 


\section{REFERENCES}

Arellano-Yanguas, J. (2012). Mining and conflict in Peru: Sowing the minerals, reaping a hail of stones. In Bebbington, A. (Ed.), Sodial conflid, economic development and extradiveindustry (pp 89-111). New York: Routledge.

Bainton, N.A. and Banks, G. (2018). Land and access: A framework for analysing mining,
migration and development in Melanesia. SustainableD evelopment. This issue.

Bainton, N.A., Ballard, C., and Gillespie, K. (2012). The end of the beginning? Mining, sacred geographies, memory and performance in Lihir. The A ustralian Journal of A nthropology 23: 22-49. doi.org /10.1111/j.1757-6547.2012.00169.x

Banks, G., Kuir-Ayius, D., Kombako, D., and Sagir, B.F. (2017). Dissecting Corporate Community Development in the Large-Scale Melanesian Mining Sector. In Filer, C., and Le Meur, P.-Y. (Eds.), LargeScale Mines and Local-Leve Politics: Between NewCaledonia and Papua NewGuinea (pp 207-228). Canberra: ANU Press.

Bebbington, A. (2015). Governing natural resources for inclusive development. In Hickey, S., et al. (Eds), The Pditics of Indusive D evelopment: Interrogating the Evidence (pp 86-115). Oxford: Oxford University Press. doi:10.1093/acprof:oso/9780198722564.001.0001

This article is protected by copyright. All rights reserved. 
Bebbington, A. (2012). Underground political ecologies. Geoforum 43(6): 1152-1162.

Bebbington, A. 2000. Re-encountering development: livelihood transitions and place transformations in the Andes. A nnals of the A ssodation of A merican Geographers 90(3): 495520. doi.org/10.1111/0004-5608.00206

Benson, P. and Kirsch, S. 2010. Corporate Oxymorons. Dialectical A nthropdogy 34(1): 45-48. doi.org/10.1007/s10624-009-9112-y

Berdegué, J., Bebbington, A., and Escobal, J. (Eds) (2015). Growth, poverty and inequality in sub-national development: learning from Latin America's territories. Special Issue of World D evelopment vol. 73.

Borras, S., et al. (2011). Towards a better understanding of global land grabbing: an editorial introduction. Joumal of Peasant Studies 38(2): 209-216. doi.org/10.1080/03066150.2011.559005

Bridge, G. (2004). Mapping the bonanza: geographies of mining investment in an era of neoliberal reform. TheProfessional Geographer 56(3): 406-421. 
doi/abs/10.1111/j.0033-0124.2004.05603009.x

Broad, R. and Fischer-Mackey, J. (2017). From extractivism towards buen vivir. mining policy as an indicator of a new development paradigm prioritising the environment. Third World Quarterly 38(6): 1327-1349. doi.org/10.1080/01436597.2016.1262741

Bury, J. (2004). Livelihoods in transition: transnational gold mining operations and local change in Cajamarca, Peru. TheGeographical Journal 170(1): 78-91. doi.org/10.1111/j.0016-7398.2004.05042.x

Cabellos, E. and Boyd, S. (2007). Tambogrande Mangos, Murder and Mining Documentary film. Lima: Guarango Films.

Cowen, M. and Shenton, R. (1998). Agrarian Doctrines of Development Part 1. Joumal of Peasant Studies 25(2): 49-76. doi.org/10.1080/03066159808438666

Cowen, M. and Shenton, R. (1996). Dodrines of Development. London: Routledge. 
Deere, C.D. (1990). Household and Class Relations: Peasants and Landlords in Northem Peru. Berkeley: University of California Press.

Edelman, M., Oya, C., and Borras, S. (2013). Global land grabs: historical processes, theoretical and methodological implications and current trajectories. Third World Quarterly (34) 9: 1517-1531. doi.org/10.1080/01436597.2013.850190

Escobar, A. (2008). Teritonies of Difference Place, Movements, Life, Redes. Durham: Duke University Press. doi.org/10.1215/9780822389439

Escobar, A. (2001). Culture sits in places: reflections on globalism and subaltern strategies of localization. Political Geography 20(2): 139-174. doi.org/10.1016/S0962-6298(00)00064-0

Filer, C. (1997). Compensation, Rent and Power in Papua New Guinea. In Toft, S. (Ed) Compensation for ResourceD evelopment in Papua NewGuined (pp 156-189). Canberra: The Australian National University.

Global Witness. (2017). Defenders of theE arth: Global Killings of L and and Environmental D fenders in 2016. London: Global Witness.

This article is protected by copyright. All rights reserved. 
Hilson, G., et al. (2017). Artisanal and small-scale mining (ASM) in Sub-Saharan Africa: reconceptualizing formalization and "illegal" activity. Geoforum 83: 80-90.

Jong, H.N. (2018). As Indonesia gears up for elections, activists brace for an environmental sell-off. Mongabay Feb19th, 2018. Retrieved from https:// news.mongabay.com/2018/02/as-indonesia-gears-up-for-elections-activistsbrace-for-an-environmental-sell-off/

King, B. (2011). Spatializing Livelihoods: resource access and livelihood spaces in South Africa. Transadions of theInstitute of British Geographers 36(2): 297-313.

Kirsch, S. (2014). Mining Capitalism: TheRdationship between Corporations and Ther Critics. Berkeley: University of California Press.

Maconachie, R. (2014). Mining for Change? Youth livelihoods and extractive industry investment in Sierra Leone. A pplied Geography 54: 275-282. doi.org/10.1016/j.apgeog.2014.05.009

Maconachie, R. and Binns, A. (2007). 'Farming miners' or 'mining farmers?': Diamond mining and rural development in post-conflict Sierra Leone. Journal of Rural Studies 23: 367-380. 
doi.org/10.1016/j.jrurstud.2007.01.003

Massey, D. (1991). A Global Sense of Place. Marxism Today. June 1991: 24-29.

Massey, D. (1984). Spatial Divisions of Labour. Social Structures and the Geographies of Production Basingstoke: MacMillan.

Owen, J.R. and Kemp, D. (2017). Extradive Relations: Countervailing Power and theGlobal Mining Industry. London: Greenleaf Publishing/Routledge.

Owen, J.R. (2016). Social licence and the fear of minerus interuptus. Geoforum 77: 102-105.

Pierce, J., Martin, D., and Murphy, J. (2011). Relational Place Making: the Networked Politics of Place. Transadions of theInstitute of British Geographers 36: 54-70. doi.org/10.1111/j.1475-5661.2010.00411.x

Schejtman, A. and Berdegué, J. (2004). Rural Teritonial Development Santiago de Chile: Rimisp.

Sen, A. (1999). Demoracy as Freedom Oxford: Oxford University Press.

This article is protected by copyright. All rights reserved. 
Serageldin, I. and Steer, A. (1994). Making Development Sustainable. From Concepts to A dion.

Environmentally sustainable development occasional paper series, No. 2. Washington, D.C.: The World Bank. doi.org/10.1596/0-8213-3042-X

Spiegel, S.J. (2014). Rural place-making, globalization and the extractive sector: Insights from gold mining areas in Kratie and Ratanakiri, Cambodia. Journal of Rural Studies 36: 300-310. doi.org/10.1016/j.jrurstud.2014.09.007

Wallerstein, I. (1974). TheModem Wordd-System, vd. I: Capitalist A grialtureand theOrigins of the E uropenn World-E conomy in theSixtenth Century. New York/London: Academic Press.

Warnaars, X. (2013). Territorial transformations in El Pangui. In Bebbington, A. and Bury J. (Eds), Subteranean Struggles: New Dynamics of Mining Oil and Gas in Latin A merica. Austin: University of Texas Press.

World Commission on Environment and Development (WCED). (1987). Our Common Future TheW orld Commission on Environment and Development. Oxford: Oxford University Press.

This article is protected by copyright. All rights reserved. 


\section{University Library}

\section{- M M I N E R VA A gateway to Melbourne's research publications}

Minerva Access is the Institutional Repository of The University of Melbourne

Author/s:

Bebbington, A;Bebbington, $\mathrm{DH}$

Title:

Mining, movements and sustainable development: Concepts for a framework

Date:

2018-09-01

Citation:

Bebbington, A. \& Bebbington, D. H. (2018). Mining, movements and sustainable development: Concepts for a framework. SUSTAINABLE DEVELOPMENT, 26 (5), pp.441-449. https://doi.org/10.1002/sd.1888.

Persistent Link:

http://hdl.handle.net/11343/284695 